\title{
VÁROSTÉRSÉGEK LEHATÁROLÁSA A KÖZÚTI FORGALOM NAGYSÁGA ALAPJÁN A MAGYAR HATÁROK MENTÉN
}

\author{
(Bordering Urban Regions with the Help of Road Traffic Flows \\ Along the National Borders of Hungary)
}

\section{SZALKAI GÁBOR}

\begin{abstract}
Kulcsszavak:
vonzáskörzet közlekedés közútiforgalom módszertan

A vonzáskörzet lehatárolások esetében gyakran jelentkezik problémaként az aktuális adatok hiánya. E hiány feloldását kínálja egy eddig ilyen célra nem használt indikátor, a közúti forgalom nagyságának alkalmazása. Az évente végrehajtott forgalomszámlálásokból származó eredmények alapján - bizonyos keretek között - megbecsülhetö a központi településekre ingázó gépjármüvek száma, s ezzel a vonzáskörzet határa is. Elemzésünkben a személygépkocsi forgalom alapján nyolc megyeszékhely vonzáskörzetének meghatározását végeztük el. Megállapítható volt, hogy a városoktól 5-15 km távolságban található az elsö jelentösebb forgalmi töréspont, amelyet átlagosan $34 \mathrm{~km}$ távolságban követ az (elsödleges) vonzáskörzet-határ. Ennél jelentösen nagyobb vonzáskörzettel csak Miskolc (40 km) és Budapest (47 km) rendelkezik. A vonzáskörzet nagysága - a fövárostól eltekintve - nem áll szoros összefüggésben a népességszámmal, függ azonban a településhálózat szerkezeti jellemzöitöl.
\end{abstract}

A települések, településcsoportok vonzáskörzetének meghatározása, lehatárolása régóta vizsgált probléma a regionális kutatásokon belül. Mind módszereit, tematikáját, mind idősíkját tekintve számos különböző dimenzióban folytattak elemzéseket, így ismeretesek általános, történeti jellegü vizsgálatok (pl. Kókai 1998; Győri 2003), történeti és jelenlegi ipari létesítményekhez kötődő kutatások (pl. Kiss 1986; Frisnyák 2007), vagy a szolgáltató szféra különböző elemeihez (pl. oktatás, telekommunikáció) köthető értekezések (Tóth 1974; Májas 2005; Teperics 2005; Fodor 2006). Lehatárolási szempontként megjelenik a közlekedés is (pl. Havellant 2005), a gyakran használt elérhetőségi vagy ingázási mutatók helyett azonban egy új paraméter, a közúti forgalom változása alapján való városkörzetek kijelölésére tettünk kísérletet.

E statisztikai adatforrás felhasználását indokolja, hogy az adatszolgáltatás szempontjából különösen rugalmas mutatóról van szó, szemben például az ingázási adatokkal, melyet csak a népszámlálások, mikrocenzusok során mérnek fel. A forgalmi adatokat az állami úthálózat forgalmasabb elemein folyamatosan rögzítik, így előzetes elvárásaink szerint nem csak egy statikus állapot felvázolására, de a vonzáskörzetek változásának kimutatására is lehetőséget kínálnak. Felhasználásuk azonban további választási kényszert is felvetett.

A közúti forgalomszámlálások gyakorlata ugyanis két típusú felvételt, a célforgalmi és a keresztmetszeti számlálások csoportját különbözteti meg. A feladat elvégzéséhez a célforgalmi számlálások eredményei lennének kedvezőbbek, mivel 
ezek a kistérségi szintnél is pontosabb földrajzi információt adnak a közlekedő járművek kiindulási és célpontjairól. Célforgalmi felvételeket az 1950-es évektől végeznek Magyarországon, periodicitásuk azonban meglehetősen esetleges, a rendszerváltást követően csak két alkalommal, 1995-ben és 2008/2009-ben került rá sor.

A forgalomfelvételek másik típusára, a keresztmetszeti számlálásokra a célforgalmi számlálásoknál jóval gyakrabban kerül sor. 1995-ben vezették be az úgynevezett gördülő számlálási rendszert, amelynek során ötévente valamennyi állami kezelésben lévő út forgalmáról forgalmi adat keletkezik, míg az éppen nem számlált útvonalak adatait évente korrigálják a megfelelő forgalomfejlődési szorzókkal. Emellett 800 keresztmetszeten üzemelnek azok a figyelemmel kísérési állomások, amelyek minden évben, adott esetben akár napi 24 órás üzemben folyamatosan adatokat szolgáltatnak a legfontosabb utak forgalmáról.

Így számos útvonalról évente frissített, mért adatok állnak rendelkezésünkre, jelenleg legutóbb a 2009. évre vonatkozóan. Vizsgálatunk elvégzésekor azonban a 2007-es adatok voltak még csak elérhetőek, így elemzésünk erre az évre vonatkozik. A keresztmetszeti adatok azonban nem adnak konkrét információt a gépjármüvek honnan-hová mozgásáról. Tanulmányunk egy olyan módszertan kidolgozását és gyakorlati megvalósítását tüzte ki célul, melynek segítségével a keresztmetszeti adatokból megfelelő valószínűséggel nyerhetők ki a várostérségek lehatárolásához szükséges információk.

\section{A vizsgálat módszertana}

A kutatás kezdő lépése a feladat pontos lehatárolása volt, melynek során több szempontból is szükíteni kellett a vizsgálandó entitások körét. Így megszorításokat kellett tenni a településhálózatra, a vizsgálati időpontokra, a gépjármü kategóriákra és az útkategóriákra vonatkozóan is.

A településhálózat szempontjából a hazai városhálózat 70 ezer főnél népesebb, határ közeli városainak (Budapest, Debrecen, Miskolc, Szeged, Pécs, Győr, Nyíregyháza, Szombathely, Tatabánya) vonzáskörzeti lehatárolását, valamint - a határon túli kapcsolatok intenzívebbé válása következtében - egyes határon túli nagyvárosok térségének vizsgálatát tüztük ki célul. E körbe azok a népes nagyvárosok kerültek be (Arad, Nagyvárad, Szatmárnémeti, Pozsony), amelyek a határok átjárhatóbbá válásával vonzáskörzetüket Magyarországra is kiterjesztették, és a napi ingázás határt átlépő utazássá vált. E folyamat a szomszédos országok állampolgárainak magyarországi ingatlanvásárlásához kapcsolódik, mivel a központjukat vesztett, periférikussá vált magyarországi területeken jóval olcsóbbak az ingatlanok, mint a határon túli nagyvárosok környékén.

Vizsgálatainkban a rendszerváltás utáni periódus kutatását tűztük ki célul, így kiindulópontként az 1990-es évtized első számlálását, az 1992. évit választottuk, a záró dátum pedig az utolsó rendelkezésre álló adatsor felmérési éve, 2007 lett. 
A 15 éves vizsgálati perióduson belül két további osztópont felvételét tartottuk megfelelőnek. A 2003-as, mint utolsó nem EU-s év kiválasztását a határon átnyúló kapcsolatok vizsgálata indokolta, 1998-ra pedig részben mint arányos tagolópontra, részben azért esett a választás, mert ez volt az az év, amikorra a forgalomváltozás tendenciái kiheverték a Bokros-csomag okozta gazdasági sokkot.

Szintén meg kellett határozni a vizsgálandó jármükategóriákat is. A keresztmetszeti számlálások során 12 járműkategóriára bontva regisztrálják a számlálási keresztmetszeten áthaladó jármüveket:

\section{Személygépkocsi}

\section{Kistehergépkocsi}

3. Egyes autóbusz

4. Csuklós autóbusz

5. Közepesen nehéz tehergépkocsi

6. Nehéz tehergépkocsi

\section{Pótkocsis tehergépkocsi}

8. Nyerges szerelvény

9. Speciális nehéz jármü

10. Motorkerékpár

11. Kerékpár

12. Lassú jármü
Személygépkocsi vontatmánnyal vagy anélkül, kisautóbusz 9 féröhely alatt Tehergépkocsi, amelynek megengedett legnagyobb össztömege kisebb 3,5 tonnánál (kivéve a 9 férőhely alattiakat)

3,5-7,5 tonna közötti össztömegü kéttengelyes tehergépkocsi 7,5 tonnánál nagyobb össztömegü két- vagy többtengelyes tehergépkocsi pótkocsi vagy vontatmány nélkül Két- vagy háromtengelyes tehergépkocsi pótkocsival Nyerges vontatóból és félpótkocsiból álló jármüszerelvény Hat- vagy ennél többtengelyes speciális nehéz jármü

A kutatás során ezen jármükategóriák közül kellett kiválasztani azokat, amelyek megfelelően reprezentálják a vonzáskörzeti mozgásokat. A különleges jármükategóriákon (speciális ill. lassú jármüvek) kívül eleve kizártuk a vizsgálatokból a kisteher-gépkocsikat, melyek mozgásjellemzői - részben a jelentős adatfelvételi hiba miatt is - nagymértékben megegyeznek a személygépkocsikéval. Szintén kizártuk a személyforgalomból rendkívül kis (a föutak többségén 5\% alatti) hányaddal részesedő motorkerékpáros közlekedés értékelését, és elhagytuk a kerékpárforgalom adatainak vizsgálatát is, hiszen a kerékpár elsősorban a településhatárt át nem lépő mozgások lebonyolításának fő eszköze; de ezen túlmenően - az észlelésekbe nem bevont kerékpárutak fokozódó kiépülése miatt - a biciklis forgalom adatai egyre kevésbé megbízhatóak. 
A lakossági helyváltoztatás értékelésére bevonható lett volna az autóbuszok forgalma is, e kategória azonban - darabszámra nézve - számos esetben alacsony értékekkel képviselteti magát, miközben a lényegi mondanivalót, a szállított utasok számát továbbra sem ismertük volna meg. A szóló buszoknál a menetrendszerinti és különbuszok forgalma sem különíthető el, a csuklós buszoknál e probléma azonban nem áll fenn. E járműkategória mozgásjellemzőit vizsgálva egyébként a körzeti forgalom legszebb képe tárul fel - szemben a szóló buszok forgalmának „távolsági” jellegével (1. ábra) -, azonban csuklós buszok nem közlekednek mindenhol az országban, így vizsgálatuk ezért sem indokolt.

\section{1. ÁBRA}

A csuklós és a szóló buszok forgalmi terhelése, 2007 (jármü/nap)

(Traffic Load of Articulated and Solo Buses, 2007 [vehicle/day])

Csuklós buszok

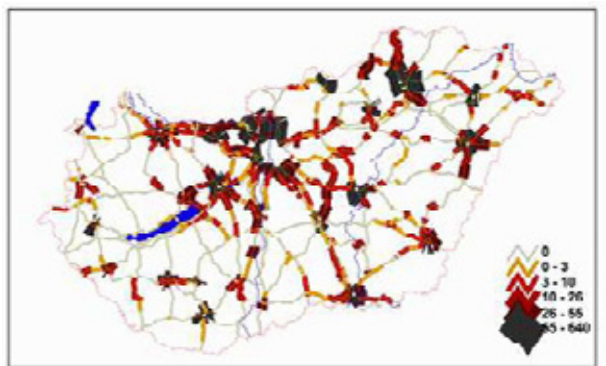

Szóló buszok

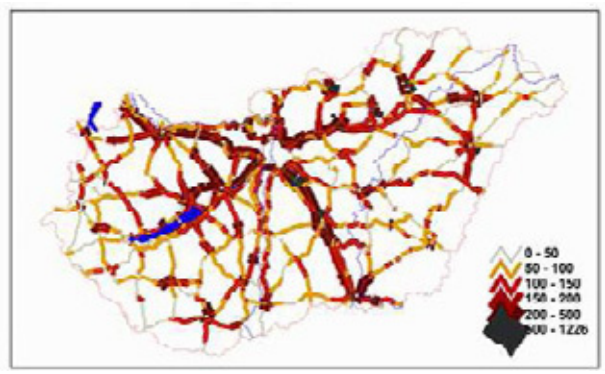

Forrás: Az országos... (2008) adatai alapján saját szerkesztés.

Így a lakossági mozgások vizsgálatát a személygépkocsik forgalmának elemzésével végeztük el. Jelen kutatás szempontjából ez, a lakossági mozgások vizsgálata volt az elsőrendü feladat, de értékeltük a teherforgalom legfontosabb mozgásjellemzőit is, megalapozva esetleges későbbi kutatásokat.

A teherforgalom esetében a pótkocsis tehergépkocsik és nyerges szerelvények forgalmának vizsgálata nem lenne célravezető. Mivel ezen jármütípusok a nagy távolságú szállítás fő eszközei, így a helyi, vonzáskörzeti forgalomban csak csekély szerepet játszanak. „Távolsági” típusú terhelési térképük (2. ábra) alapján megállapítható, hogy míg a pótkocsis tehergépkocsik használata inkább a belföldi, nagyvárosok közötti forgalomban jellemző, addig a nyerges szerelvények a legfontosabb tranzit útvonalakat rajzolják ki. E jármükategóriáknál a maximumértékek nem a klasszikus városközpontokhoz kötődnek, a várostól való távolság és a forgalom nagysága között nincsen szignifikáns kapcsolat. 


\section{2. ÁBRA}

A pótkocsis tehergépkocsik és nyerges szerelvények forgalmi terhelése, 2007

(Traffic Load of Lorries with Trailers and Camions, 2007 [vehicle/day]) pótkocsis tehergépkocsik nyerges szerelvények
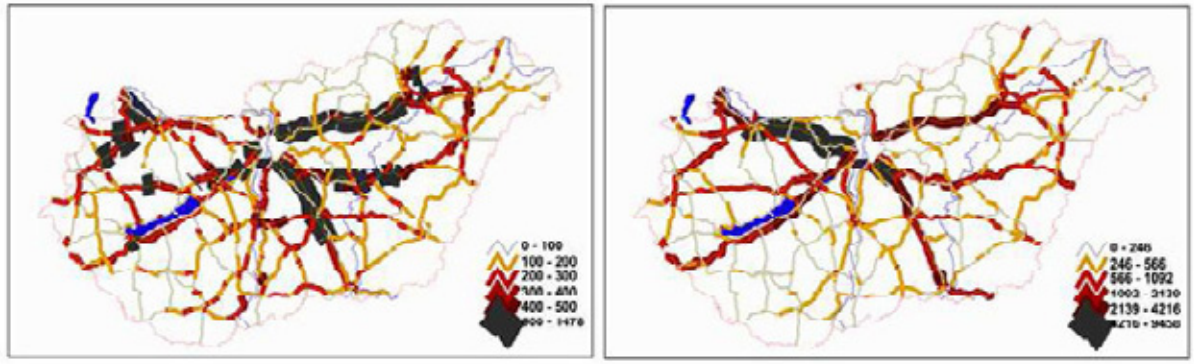

Forrás: Az országos... (2008) adatai alapján saját szerkesztés.

Ennek alapján a teherforgalom vizsgálatának eszköze a közepesen nehéz és a nehéz tehergépkocsik mozgásjellemzőinek (3. ábra) értékelése lesz. Előzetes vizsgálataink alapján e tehergépjármü-kategóriák esetében kimutatható vonzáskörzeti forgalom, a csúcs a városközponti szelvényekre esik, de a külső szakaszokon mért forgalomhoz viszonyítva az eltérés mértéke kisebb, mint a személygépkocsiknál. Vagyis a forgalmi görbe simítottabb, a várostól távolodva csökken a forgalom nagysága, de a csökkenés mértéke kisebb a kisebb csúcs miatt.

\section{3. ÁBRA}

A középnehéz és nehéz tehergépkocsik forgalmi terhelése, 2007 (jármü/nap)

(Traffic Load of Medium Heavy and Heavy Lorries, 2007 [vehicle/day]) középnehéz tehergépkocsik

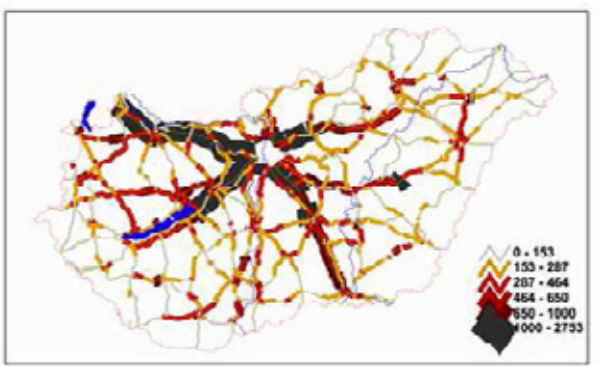

nehéz tehergépkocsik

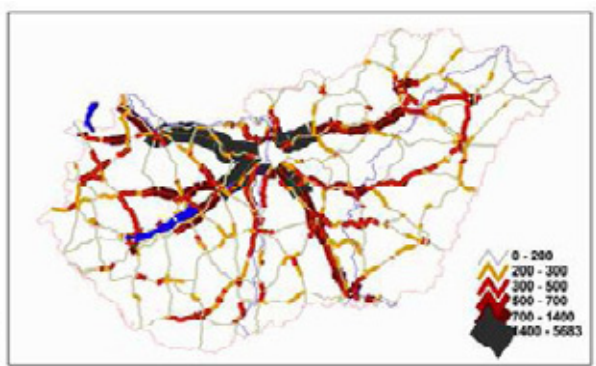

Forrás: Az országos... (2008) adatai alapján saját szerkesztés.

Végül meg kellett állapítani, hogy az országos közúthálózat mely elemeit célszerü bevonni a vizsgálatba.

A kutatások kimutatták, hogy az autópályák nem vonhatók be a vizsgálatba, mivel forgalmuk elsősorban a nagytérségi-nemzetközi szinthez kapcsolódik. Ahogyan a főváros lakosságszámával és gazdasági súlyával egyaránt kiemelkedik a hazai város- 
hálózatból és inkább az európai nagyvárosi hálózat egyenrangú tagja, ugyanúgy állnak a gyorsforgalmi utak is a hazai közúthálózat felett. Bár zajlik rajtuk (a díjasítás óta lecsökkent mértékü) kistérségi vonzáskörzeti forgalom, ennek mértéke azonban a teljes forgalmi volumenhez képest annyira elhanyagolható, hogy bármiféle célforgalmi következtetés levonása lehetetlen. Ez alól az egyetlen kivételt a - tranzit levonása után is jelentős mértékü - fővárosba irányuló forgalom jelenti, a gyorsforgalmi utakon Budapest a teljes országra kiterjeszti vonzáskörzetét (4. ábra).

\section{4. ÁBRA}

Autópályáink személygépkocsi forgalma, 2007 (jármü/nap)

(Traffic Load of Cars on the Motorways, 2007 [vehicle/day])

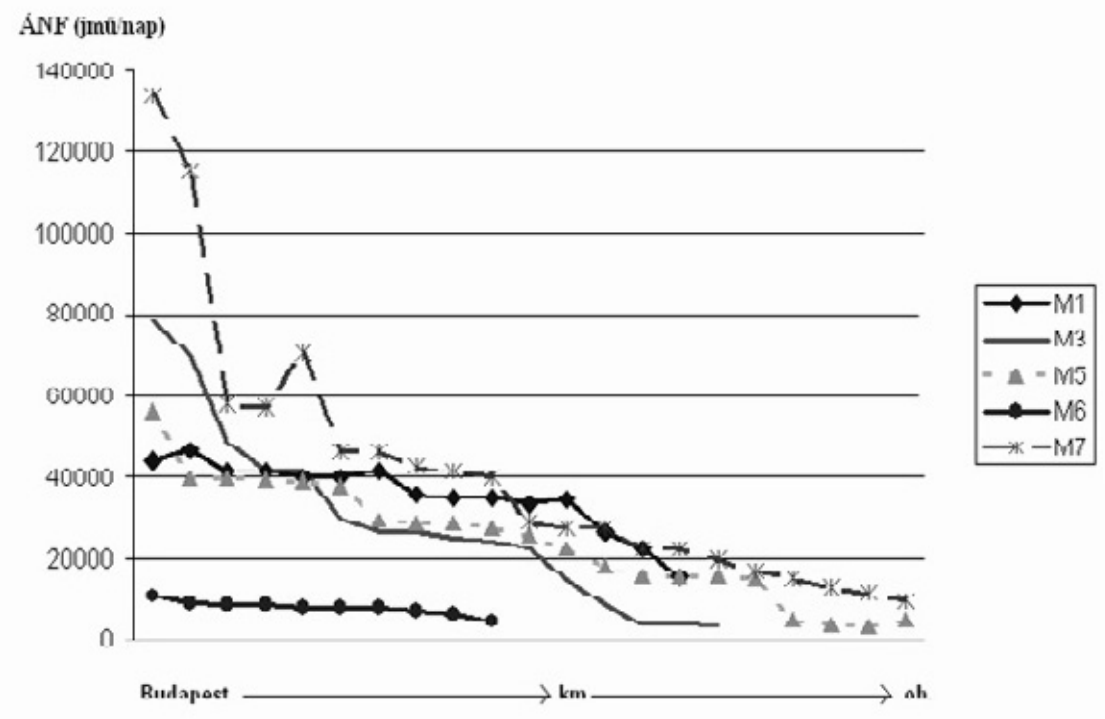

Forrás: Az országos... (2008) adatai alapján saját szerkesztés.

Gyorsforgalmi útjaink forgalmát megvizsgálva ugyanis megállapítható, hogy szinte kivétel nélkül monoton csökkenő a terhelés a határok felé, amely éles ellentétben áll a közúthálózat többi tagjának a településhálózathoz kötődő, fluktuáló forgalomnagyságával. A gyorsforgalmi hálózaton Budapest az „egyetlen” központ, egy település sem képes megfordítani a fővárostól távolodva fellépő, csökkenő forgalmi trendet. Ilyen módon az autópályák elsődleges szerepe nem a vidéki területek feltárása, hanem sokkal inkább a főváros jobb elérhetőségének biztosítása.

Ugyanakkor fóútjaink (föleg az autópálya hálózat kiépítését követően) élő kapcsolatban vannak az általuk érintett településekkel, a forgalom nagyságát a külső és az átkelési szakaszok váltakozása határozza meg. Példaképen a 3. sz. fóút személygépkocsi forgalmát mutatja az 5. ábra. 


\section{5. ÁBRA}

A 3. sz. föút személygépkocsi forgalma, 2007 (jármü/nap)

(Traffic Load of Cars on the Road Nr. 3, 2007 [vehicle/day])

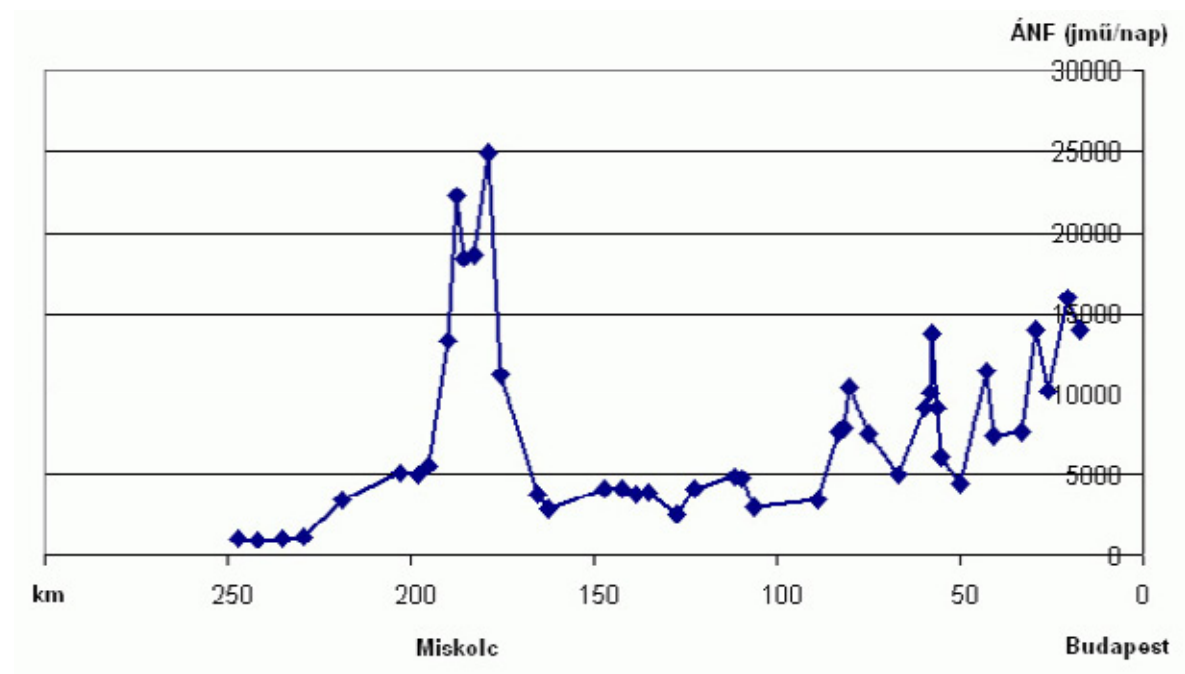

Forrás: Az országos... (2008) adatai alapján saját szerkesztés.

Az autópályák mellett az úthálózati hierarchia alsó elemeinek vizsgálatát is el kellett vetni. Bár egyes hosszabb, összekötő utak alkalmasak lehetnek célforgalmi megállapítások megtételére, a számos rövid, észlelési pontokkal ritkábban ellátott útszakaszon a forgalom „követhetetlenül” áramlik. Nem állapítható meg, hogy egy-egy csomópontnál milyen irányú a forgalom, vagy csak maga a település volt a cél; így végül a kutatásba csak az első- és másodrendü főutak hálózatát vontuk be. Ez a hálózat még kellő sürüséget biztosít, megfelelően lefedi az országot, ugyanakkor a relatív hosszabb utak forgalmából, a forgalom fluktuációjából célforgalmi következtetéseket is le lehet vonni.

E megszorítás ugyanakkor azzal a következménnyel jár, hogy a forgalmi alapon történő vonzáskörzet-lehatárolás nem ad településsoros mátrixot, azaz csak kitüntetett vonalak mentén vagyunk képes a határokra becslést adni.

E módszer a vizsgálandó települések közül kettőben nem, vagy csak részlegesen alkalmazható. A föváros az egyik, melynek vonzáskörzete - az autópályák kapcsán említett hatás miatt - csak korlátozottan állapítható meg. Budapest vonzáskörzete ilyen módon országos szintű, az autópályák révén az egész országra kiterjed, azonban a közelebbi célpontok esetében - a gyorsforgalmi utakon történő és „,nem mérhető” ingázás miatt - információt vesztünk.

A másik település, ahol nehézkes a módszer alkalmazása, Tatabánya. A legkisebb, a 70 ezres lélekszámot mindössze 333 fővel meghaladó város ugyanis nem szerves fejlődés során alakult ki, és ez rányomja bélyegét a közúthálózati ellátottságra is. A bányászat hatására a 20 . század elején növekedésnek indult településegyüttes 
korábban jelentéktelen volt, így az 1950-es évekig még másodrendű főút sem érintette. Jelenleg is csak egyetlen föúti tengely (M1-1) érinti, amely messze a legroszszabb ellátottságot jelenti nagyvárosaink közül. A fő probléma, hogy az autópálya jelentősen ,zavarja” az 1-es út forgalmi viszonyait, a Tata felé irányuló forgalom összeolvad az autópályáról lehajtóval, így csak egyetlen értékelhető tengely maradt, Bicske irányába. Ez viszont kevés ahhoz, hogy értékelhető eredményt kapjunk, így Tatabányát kihagytuk a vizsgálatokból.

A fenti megfontolásokat és megszorításokat követően a vizsgált négy év forgalmi adatbázisainak hibamentesítése, majd az adatsorok kódolása következett. Minden vizsgált föúton el kellett helyezni a vizsgálatba vont településeket, és olyan új távolságértékeket kellett számítani, ahol a vizsgált település került az origóba. Számos esetben, ahol a vonzáskörzetek egymásba fonódnak, a kérdéses útszakaszokat meg kellett duplázni, hogy azok mindkét érintett településhez hozzárendelhetők legyenek. Az így kibővített adatbázison futtattuk le a külön erre a célra írott makrónkat, amely elkészítette a vizsgálathoz szükséges 228 forgalmi grafikont, amelyek a városoktól való távolság függvényében ábrázolják a személygépkocsi forgalmat. Ezzel párhuzamosan elkészítettük minden évre vonatkozóan a személygépkocsi forgalom országos terhelési térképeit is (6. ábra).

\section{6. ÁBRA}

A föutak személygépkocsi forgalma, 1992, 1998, 2003, 2007 (jármü/nap) (Traffic Load of Cars on the Main Roads, 1992, 1998, 2003, 2007 [vehicle/day])

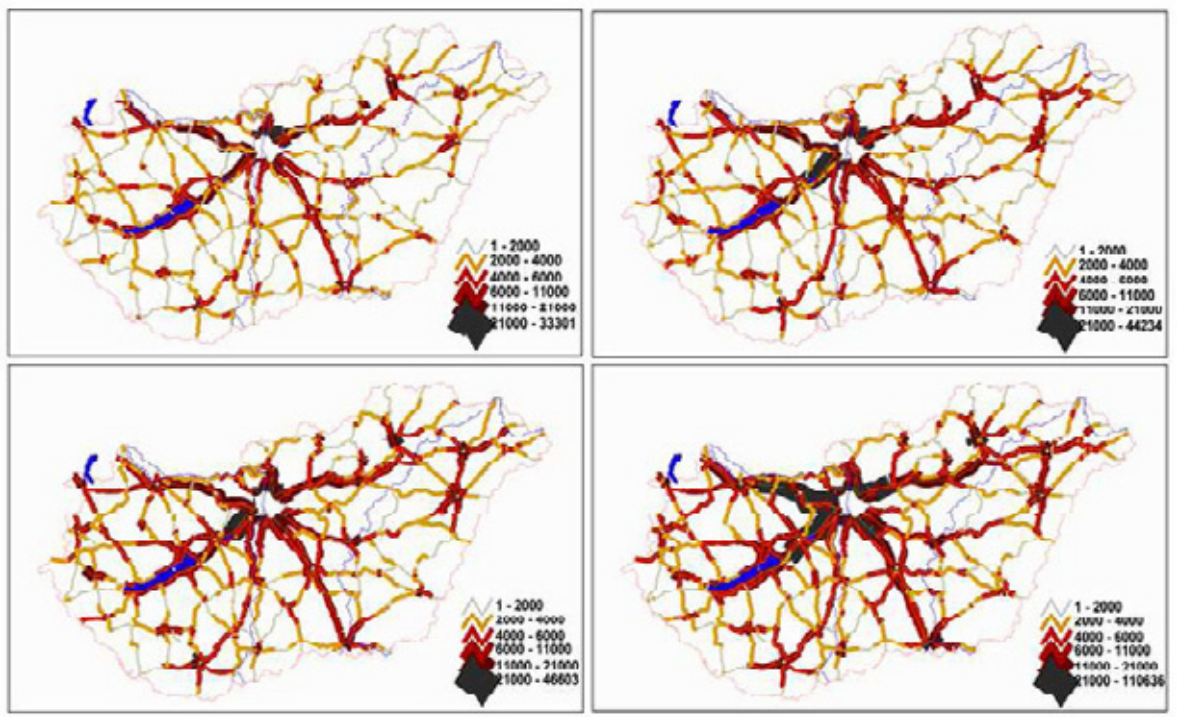

Forrás: Az országos... (1994; 1999; 2004; 2008) adatai alapján saját szerkesztés.

Az összehasonlíthatóság miatt azonos kategória beosztással szerkesztett térképeken csak a legfelső értékkategória mozog, jelezve, hogy 1992 óta jelentős forgalomnövekedés ment végbe közútjainkon. A távolsági forgalom mellett kirajzolódnak 
a fontosabb települések forgalmi gócpontjai is, a térképi ábrázolás alapján azonban nem határolhatók le pontosan a vonzáskörzetek. A térképek a vizsgálat során inkább a térbeli orientációt segítették, a forgalom részletes vizsgálata azonban a forgalmi diagramok alapján történt (7. ábra). A térképek azonban ennek ellenére sem hagyhatók figyelmen kívül, hiszen a grafikonok alapján nem ítélhető meg, hogy egy adott forgalmi töréspont településhálózati vagy úthálózati hatásra jött-e létre.

\section{7. ÁBRA}

A 83. sz. föút személygépkocsi forgalma, 2003, 2007 (jármü/nap)

(Traffic Load of Cars on the Road Nr. 83, 2003, 2007 [vehicle/day])

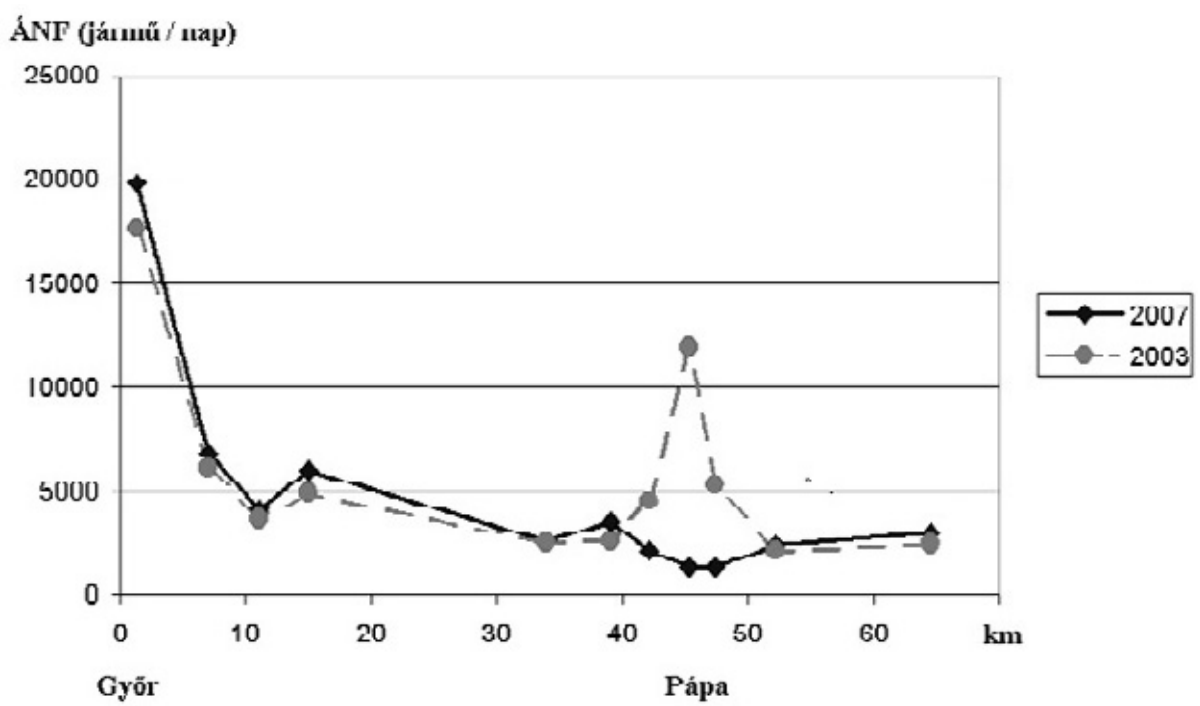

Forrás: Az országos... (2004; 2008) adatai alapján saját szerkesztés.

A derékszögü koordináta rendszerben ábrázolt forgalmi grafikonok x tengelyén a vizsgált útvonal kilométer szelvényezése kapott helyet, míg az y tengelyen az átlagos napi személygépkocsi forgalom (ÁNF) megadására került sor. A különböző évekre vonatkozó szelvénybeosztás egységesítése után lehetővé vált több év adatsorának egy grafikonon való ábrázolása is, amely a 17 év alatt bekövetkezett forgalmi változások elemzését segítette.

Az eredmények értékelése során számos technikai paramétert figyelembe kellett venni. Így fel kellett térképezni a mindenkori úthálózati viszonyokat, hiszen a keresztmetszeti statisztikák minden esetben az adott úthálózati állapotra vonatkoznak, vagyis - mint ahogyan a 3. ábrán is megfigyelhető - a 83. sz. fóút földrajzilag nem ugyanazt az útszakaszt jelentette 2003-ban és 2007-ben. A mellékelt diagram tehát nem arra enged következtetni, hogy 2003-ról 2007-re Pápa térségében drasztikusan lecsökkent a forgalom, hanem a pápai elkerülő megépítése miatt a forgalmilag terhelt átkelési szakaszok kikerültek a 83-as szám alatt nyilvántartott út statisztikájából. 
A hálózati változások nyomon követése tehát alapfeltétel, enélkül téves következtetésekre juthatunk a változások magyarázata során.

Ugyanígy befolyásolja a forgalomáramlási irányokat a párhuzamos gyorsforgalmi utak kiépítése is. Az autópályákkal párhuzamos főutakról - nagyobb távolságú ingázás esetén - a forgalom a gyorsforgalmi utakra terelődik, így több esetben elöfordul, hogy a foút szerepe csak a településközi forgalom lebonyolítására korlátozódik. Ekkor a forgalmi görbe kisimul, és egy-egy nagyobb település „kiugrásán” kívül semmi sem állapítható meg belöle.

A változások mellett az úthálózati kapcsolatokra is tekintettel kell lenni. Csak a grafikonok és a forgalmi térképek együttes elemzésével állapítható meg, hogy a forgalom volumenének megváltozása valamely település hatására, vagy egy beágazó út miatt következett-e be. Szintén nyomon kell követni maguknak a mérési pontoknak a változását is, a mérési pontok sürüsége, elhelyezése nagymértékben meghatározza a levonható következtetések érvényességét. Egyik évről a másikra egy-egy új pont beállítása vagy megszüntetése a vonzáskörzet elmozdulásának téves megállapításához is vezethet.

A diagramok értékelésének alapvető szempontja a vizsgált város felé irányuló forgalom görbéjének növekedése volt. Alapesetben a görbe növekvő szakasza jelöli ki a vonzáskörzetet, azaz a legegyszerübb esetben a várostól távolodva fokozatosan csökken a görbe meredeksége, majd egy küszöbpont után a lejtő a másik irányba kezd emelkedni, egy másik város vonzáskörzetét jelezve ezzel. Ilyen esetben a vonzáskörzet lehatárolása egyszerü, a küszöbpontot követően meg kell keresni az elsö települést, és ez lesz a vonzáskörzet elsődleges határa.

Ez a lehatárolás természetesen nem azt jelenti, hogy ennél távolabbról nincs (akár napi ingázó) forgalom a vizsgált nagyvárosba, hiszen a görbe legalacsonyabb pontja alatti terület által reprezentált forgalmi volumen akár a teljes útszakasz hosszában is közlekedhet. Az elsődleges vonzáskörzet határ azt jelenti, hogy az adott térséget követően nagymértékben csökken a kapcsolatok intenzitása, és a keresztmetszeti számlálási elvből következően a távolabbi térségekre nem tehető felelös célforgalmi „,becslés”.

Nagyon gyakori eset azonban, hogy az első küszöbpontot követően egy olyan kisváros kiemelkedő forgalmi értéke következik, amely még a nagyváros vonzáskörzetébe tartozik, de kiugró belső forgalma miatt a görbe nem monoton növekvő a központ felé. A kisvárosi átkelési szelvény után a forgalom átmenetileg visszaesik, majd a távolság csökkenésével a görbe újra a központ felé kezd emelkedni. Ilyen esetben a vonzáskörzetbe való besorolás feltétele az, hogy (a nagyvároshoz közeledő ingázó szemével nézve) a kisváros előtti utolsó pont és a város utáni első pont között forgalomnövekedés következzen be. Ez utal ugyanis arra, hogy az adott kisváros nem egy önmagában álló sziget, hanem forgalmával a távolsági forgalmi alaphoz képes hozzájárulni, és a forgalmi volument magasabb szintre helyezni.

Ekkor tehát a vonzáskörzetet ki kell terjeszteni a kisvárosra is, az elsődleges határpont hátracsúszik a kisvárosig, és egyben harmadik lépcsőként meg kell vizsgálni a forgalmi lejtő város előtti futását. Elképzelhető ugyanis, hogy nem maga a város, hanem egy még távolabbi pont lesz a vonzáskörzet ,végsö" határa, amely bár 
egyre kisebb hozzáadott forgalommal, de még az adott nagyváros felé gravitál. Az ilyen másodlagos határpontok kijelölése azonban nem kockázatmentes, hiszen az is elképzelhetö, hogy a kisváros felé bővülö forgalom már nem a fö központ, hanem a kisváros vonzásába tartozik. (Ilyen összetett esetre jó példa Szeged ismertetése során a 11. ábra).

Összességében tehát a fő cél az elsődleges vonzáskörzetek meghatározása, melyet kiegészíthet egy háttérzóna; minél távolabb vagyunk azonban a vizsgált településtől, annál bizonytalanabb a célforgalmi megállapítás érvényessége.

\section{A vizsgált nagyvárosok vonzáskörzeteinek lehatárolása}

A vizsgálat során Magyarország 70 ezer főnél népesebb határ közeli fekvésủ nagyvárosainak vonzáskörzetét tanulmányoztuk. A kilenc település közül módszerünkkel Tatabánya csak korlátozottan volt vizsgálható, így az egykori bányászvárost elhagytuk az elemzésből.

Pécs

Pécs egy elsőrendủ és három másodrendủ úton keresztül kapcsolódik az országos hálózatba, melyek közül csak a 6-os és a 66-os út teremt összeköttetést az ország központi területei felé.

Keleti irányba Pécs vonzáskörzete meglehetősen szük, már Zengővárkonyt $(20 \mathrm{~km})$ követően az ország központi része felé indul növekedésnek a forgalom. E választóvonal egybevág a domborzati-vízrajzi határokkal - Mecseknádasdtól Bonyhád felé „lejt” a terep. Nyugati irányba a 40 km-re fekvő kisváros, Szigetvár a vonzáskörzet „vége” (a kiemelkedő forgalmi csúcs oka már a város, maga), innen a horvát határ felé radikális törést jelez a forgalmi görbe, mintha a személygépkocsi forgalom „elfogyna” a 6-os útról (8. ábra).

Észak felé a 66-os úton a számlálási szelvények rossz megválasztása miatt nem mutatható ki megfelelően a Pécs és Komló közötti forgalom, Komló - amely „,párhuzamosan" fekszik a föúttal -, leginkább a forgalom hiányából érzékelhetö. A 66-os úton a forgalom a 611-es út csomópontjától csökken le jelentősen, a vonzáskörzet határa Sásd térségében jelölhető ki, Dombóvár hatása egyértelműen megjelenik Baranya megye területén.

Az 58-as út teljes 33 km-re Drávaszabolcsig Pécs vonzáskörzetébe tartozik, míg az 57-es úton, Pécstől 15 km-re Mohács felé elsődleges vonzáskörzet-határ helyezkedik el, a másodlagos határ azonban Mohácsig terjed.

A 15 éves vizsgálati periódusban Pécs vonzáskörzete nem változott lényegesen, egyedül Szigetvár helyi forgalmának megnövekedése változtatta meg a görbe alakját az ezredforduló után. 
8. ÁBRA

A 6-os út személygépkocsi forgalma Pécs térségében, 2007

(Traffic Load of Cars on the Road Nr. 6 in the Vicinity of Pécs, 2007)

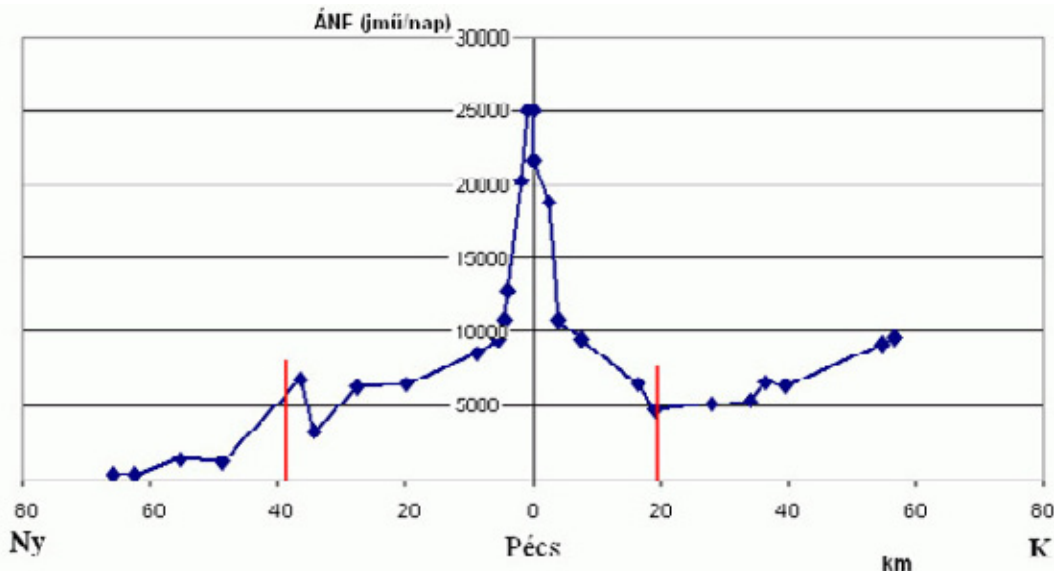

Forrás: Az országos... (2008) adatai alapján saját szerkesztés.

Györ

Győr szintén hat fő́ttal (és autópályával) kapcsolódik az országos közúthálózatba. Az 1-es úton Győr vonzáskörzete Györ-Moson-Sopron megye határáig, Nagyszentjánosig terjed. A meglehetősen rövid, 23 km-es távolság Komárom közelségének tudható be, amely a megyehatár túloldalán fekvő települések elsődleges központja. Északnyugat felé a megyeközpont vonzáskörzete az országhatárig (Hegyeshalom) terjed, hasonlóan a 14. sz. fóúthoz, Vámosszabadi irányába.

A Székesfehérvárt Györrel összekötő, 81-es út esetében 1992-töl folyamatában követhető a vonzáskörzet határ „,kinyílása”. 1998-ra vált egyértelműen hangsúlyossá az elsődleges vonzáskörzeti határ Mór térségében, és a másodlagos Kisbérnél. A Győr felé nagyjából félúton fekvő és mindkét irányba gravitáló kisváros „,vonzódása" azonban fokozatosan Székesfehérvár felé tolódott, a 2003-ig nagyjából szimmetrikus görbe 2007-re Fehérvár felé nyílt ki a forgalom volumenének általános növekedése mellett (9. ábra).

A Győr és Veszprém közötti 82. sz. út városhiányos térségeken halad át. Zirc, az egyedüli nagyobb város, már Veszprém vonzáskörzetében fekszik. Ebböl (is) következően az útvonal személyforgalma meglehetösen homogén, a teljes vizsgálati időszakban 2000-3000 gépkocsi között mozgott. A kismértékủ törések alapján azonban a vonzáskörzet mozgása rajzolódik ki, mely összefüggésben áll az 1998 és 2003 közötti közigazgatási változásokkal, amikor két részletben nyolc, a 82-es út mentén fekvő település szavazta meg a Veszprém megyétől Győr-Moson-Sopron megyéhez való csatlakozást. Míg 1992-ben Győrtől 27 km-re helyezkedett el a forgalmi minimumpont, addig az ezredfordulót követően ez hat kilométerrel délebbre tolódott, a megyét váltott települések mögé (10. ábra). 
A szintén Győrtől déli irányba induló 83. sz. főúton Pápáig terjed ki a megyeközpont vonzáskörzete, míg nyugatra, a Sopron irányába tartó 85 . sz. úton Csorna és Kapuvár közt jelölhető ki a vonzáskörzet határa.

\section{9. ÁBRA}

A Székesfehérvár és Györ közötti személygépkocsi forgalom változása (Change of Traffic Load of Cars between Székesfehérvár and Györ)

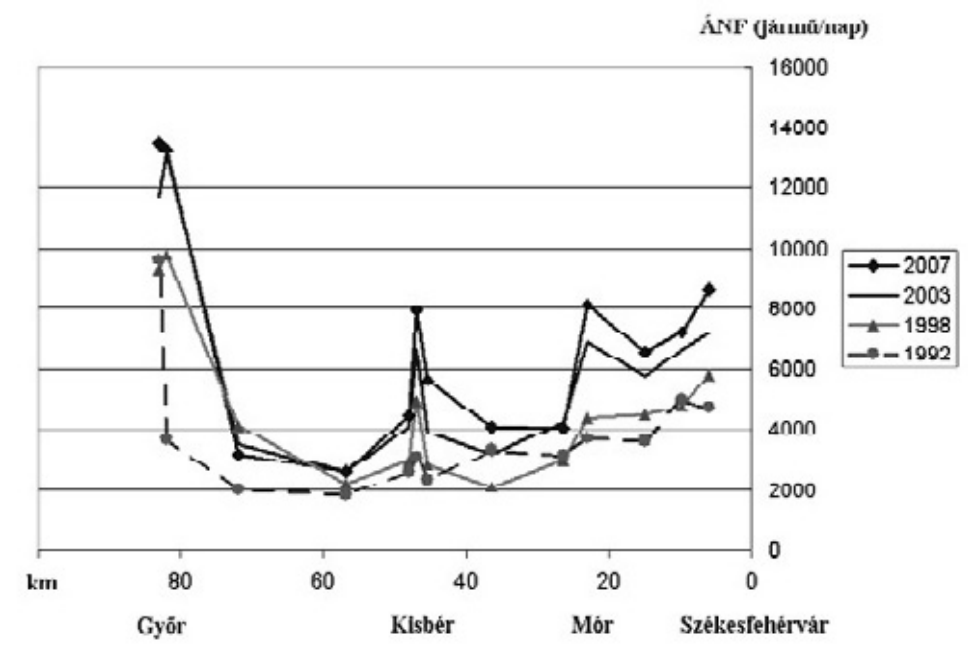

Forrás: Az országos... (1994; 1999; 2004; 2008) adatai alapján saját szerkesztés.

10. ÁBRA

A személygépkocsi forgalom és a megyehatár változása a 82. sz. föút Györ alatti szakaszán

(Change of Traffic Load of Cars and the County Border on the Road Nr. 82 to the south to Györ)

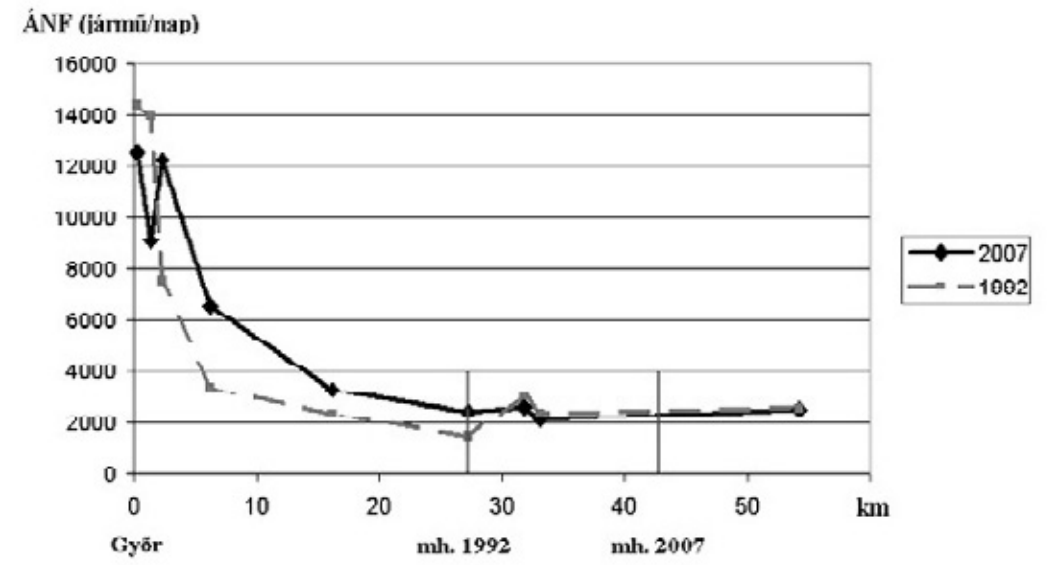

Forrás: Az országos... (1994; 2008) adatai alapján saját szerkesztés. 


\section{Szombathely}

Az elkerülő gyürü elkészültével valójában a vasi megyeszékhelyet már nem érintik föutak. A vonzáskörzet határa dél felöl a 86-os úton 42 km-nél, a megyehatárhoz kötődik, a személygépkocsi forgalom nagysága nominális értékben is rendkívül lecsökken, naponta 700-500 gépkocsira. Északkeleti irányba a 84-es úttal való kereszteződés jelent töréspontot, a forgalom innen mindkét irányba növekszik a 86-os úton.

A rövid 87-es úton Szombathely vonzáskörzete mind északi, mind déli irányba az útvonal teljes hosszára kiterjed, nehéz azonban magyarázatot találni arra, hogy 1998-ban az osztrák határ felöl miért fokozatosan csökkenő forgalom volt jellemző, szinte az útvonal teljes hosszában. A Bucsu felé vezető 89-es út menti térségek az osztrák határig, az út teljes hosszában Szombathely vonzáskörzetébe tartoznak.

\section{Szeged}

Szeged megközelíthetőségében szintén jelentős változások történtek a vizsgálati periódusban, 2005 decemberében ugyanis a város rákapcsolódott a gyorsforgalmi úthálózatra. Ez természetesen befolyásolta a vizsgálandó 5. sz. főút forgalmát is, amely mentesült a tranzitforgalom túlnyomó részétől, így forgalma a vizsgált évek közül jelenleg a legalacsonyabb. Csongrád és Bács-Kiskun megye határa egyedül 1992-ben jelent meg éles töréspontként, azt követően e vonzáskörzet határ fokozatosan megszünt, és a forgalom minimumpontja egészen Kiskunfélegyházáig tolódott hátra. Egy ilyen, 50 km-es távolságon történő ingázás azonban biztos, hogy áthelyeződik az autópályára, így a határ nagyon gyenge tagolópontok alapján Kistelek térségébe tehető. Az 5-ös út folytatásában, Szegedtől délre a vonzáskörzet határát az országhatár jelöli ki.

A román határ felé, a 43-as úton kettős vonzáskörzet-határ állapítható meg. Makó egyértelműen az elsődleges határ, innen nő meg igazán jelentős mértékben a Szeged felé tartó forgalom. Ugyanakkor Nagylaktól Makóig is folyamatosan növekvő forgalmat tapasztalunk, az azonban nem állapítható meg a keresztmetszeti adatok alapján, hogy e forgalom hogyan oszlik meg Makó és Szeged között (11. ábra).

Békéscsaba irányába a 47-es úton Hódmezővásárhely jelenti az elsődleges vonzáskörzet-határt, a várost követően az út forgalma több mint kétszeresére növekszik, de másodlagos választóvonalként a megyehatár is megadható, a 47-es út forgalma innen kezd el növekedni Szeged irányába.

Baja felé városhiányos térségen halad át az 55-ös út, a forgalmi mélypont elsődleges határként a megyehatárral esik egybe, ezen azonban túlnyúlik Szeged vonzáskörzete és 60-70 km távolságig, Mélykútig érezteti hatását a csongrádi megyeszékhely. 
11. ÁBRA

A személygépkocsi forgalom változása a 43. sz. úton, 2007

(Change of Traffic Load of Cars on the Road Nr. 43, 2007)

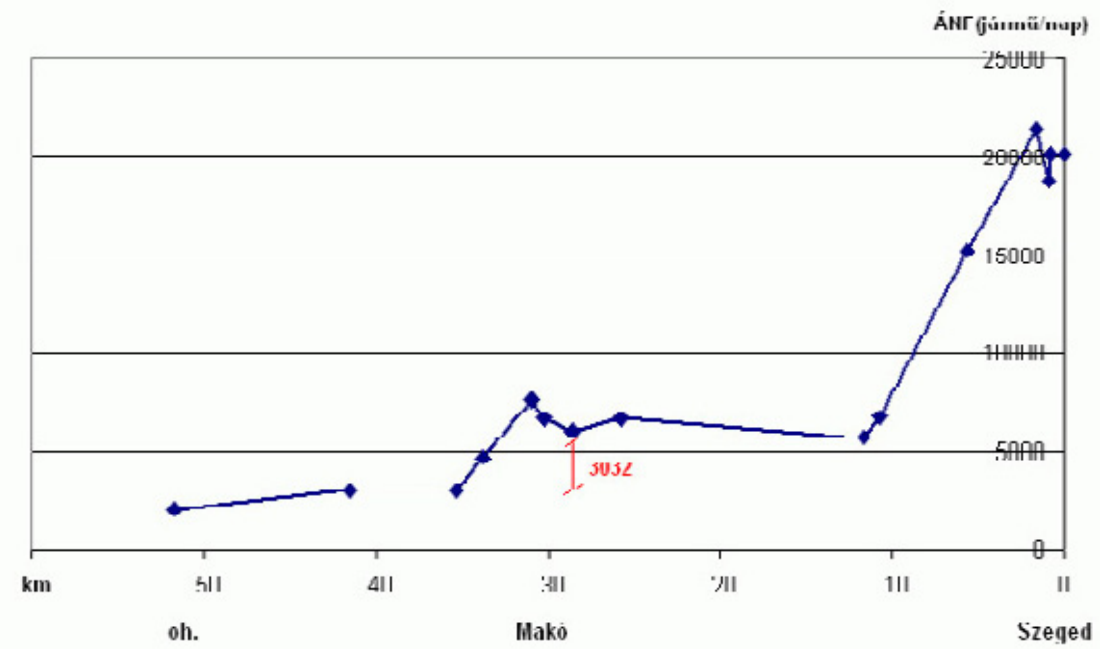

Forrás: Az országos... (2008) adatai alapján saját szerkesztés.

\section{Debrecen}

Debrecen hat föút és az M35-ös autópálya révén kapcsolódik az országos közúthálózatba. A korábbi fő tengelyt jelentő 4-es úton az ezredforduló előtt Kaba térségében volt megállapítható a vonzáskörzet határa, meg kell azonban jegyezni, hogy a következő mérési pont a 17 km-re fekvő megyehatár volt, átugorva Püspökladányt és a 42. sz. út kereszteződését. 2003-ra a korábbi éles választópont eltünt, illetve új mérési pontot állítottak fel Püspökladánynál, amely alapján itt jelölhető ki Debrecen vonzáskörzetének határa. Nyíregyháza irányába Debrecen vonzása átlépi a megyehatárt, Újfehértó egyaránt tartozik a hajdúsági, mind a szabolcsi megyeszékhelyhez.

A 33. sz. föút a Hortobágyon keresztül kiterjedt lakatlan területeken halad át, amelyet Debrecen vonzása sem ível át, a határ az „utolsó lakott” településnél, Nagyhegyesnél húzódik (12. ábra).

Ugyanez a helyzet a 35. sz. föút esetében, ahol Hajdúböszörményt követően 25-30 km-re található az első (önálló) település. Ez a távolság szintén választóvonal, az addigi 6000-10 000 gépkocsi helyett kevesebb, mint 2000-re csökken a forgalom Miskolc felé. 
12. ÁBRA

Személygépkocsi forgalom a 33-as úton, Debrecen térségében (2007)

(Traffic Load of Cars on the Road Nr. 33 in the Vicinity of Debrecen, 2007)

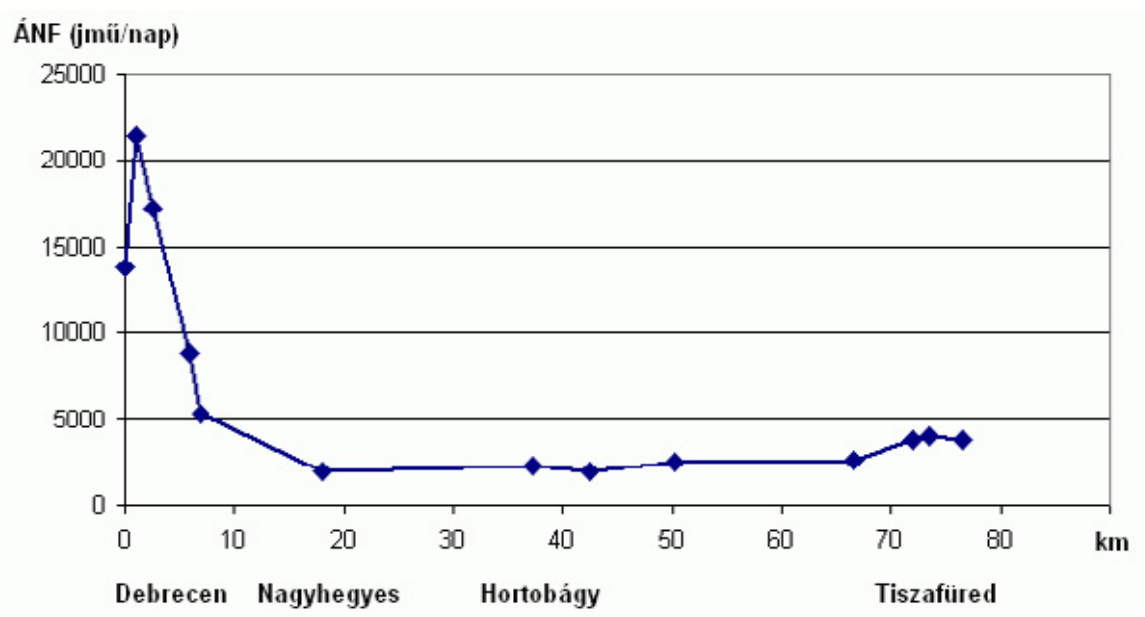

Forrás: Az országos... (2008) adatai alapján saját szerkesztés.

A 47-es úton Szeged felé két kisváros, Derecske és Berettyóújfalu található a vonzáskörzeten belül, ez utóbbin túl azonban már „,nem terjed túl” Debrecen vonzása. Az Érmihályfalva felé vezető 48 -as út mentén a román határig terjed a hazai vonzáskörzet, míg a 471-es úton a Nyíradony (és egyben a megyehatár) jelenti a választóvonalat.

Nyíregyháza

A szabolcsi megyeszékhely vonzáskörzete, ahogyan az már a Debrecenről szóló résznél kiderült, Újfehértónál kerül fedésbe a hajdúsági megyeközpontéval. A 4-es út további szakaszán a Demecser térségi falvak jelentik az elsődleges vonzáshatárt, a megyeközpont másodlagos, gyengébb vonzása azonban egészen az ukrán határig érvényesül.

A 41-es úton szintén eléri az ukrán határt Nyíregyháza vonzáskörzete (amely egyben a határon túlnyúló vonzáskörzetre is utal), itt is - csakúgy mint Záhony felé megfigyelhető azonban, hogy a kilencvenes évekhez képest csökkent az ingázási távolság. Míg kezdetben Nyíregyháza volt a fö központ, addig az ezredforduló utáni évekre jellemzőbbé vált, hogy a Vásárosnamény (és Kisvárda) markánsabb osztóponttá vált a forgalmi áramokban. Így Nyíregyháza vonzó hatása gyengült, s az ezredforduló utáni évekre megerősödött egy köztes határ a Vásárosnamény elötti falvak térségében.

A 36-os úton az első és az utolsó vizsgálati évre állapítható meg, hogy Tiszavasvári vonzáskörzet-határként viselkedett, a köztes években pedig a határ a megyeszékhelyhez közelebb húzódhatott.

A zempléni térség felé vezető 38-as úton maga Tokaj látszik határpontot képezni. A forgalmi görbe negatív törése azonban az idegenforgalmi jelentőséggel eleve nem 
fér össze, a csökkenést az okozza, hogy a Miskolc felé tartó forgalom egy része letér a fóútról, és Tarcalon keresztül (3615. sz. út) éri el a 37. sz. főutat. Amennyiben a két útszakasz forgalmát összegezzük, kiderül, hogy Tokaj valójában forgalmi nyelőpont, a két út forgalmának összege ugyanis jelentősen meghaladja a Nyíregyháza felé továbbhaladó forgalmi áram nagyságát. A megyeközpont vonzása az útszakaszon csak 15 km távolságig, a bokortanyás településtípus végéig mutatható ki.

Miskolc

A borsodi megyeközpont forgalmi helyzete is jelentősen megváltozott a vizsgálati időszakban. A 3-as út forgalma az M3-M30 átadása utáni időszakban ad megfelelő információt a vonzáskörzeti forgalomról. A 2003-as és 2007-es adatok alapján Mezőkövesd (megyehatár) jelölhető ki nyugati irányban vonzáshatárként, míg észak felé egészen a szlovák határig érezhető Miskolc hatása. Ugyanez a helyzet a 26-os úton is, ahol fokozatosan csökken a forgalom Bánrévéig.

A 35-ös út forgalmát szintén jelentősen megváltoztatta az autópályák átadása, a vonzáskörzet határa itt is egybeesik a megyehatárral, Tiszaújvárosig terjed. A 37-es úton az elsődleges határt Szerencs jelenti, de az ezredforduló körüli években megfigyelhető volt egy másodlagos vonzáshatár is, amely egészen Sárospatakig terjedt.

\section{Budapest}

A főváros az autópálya-hálózat révén az egész országra kiterjeszti vonzáskörzetét. Forgalmi adatai azonban nem teszik lehetővé a részletesebb, szükebb vonzáskörzet lehatárolását, ez csak a föutak forgalmának vizsgálatával lehetséges.

A főutak közül az 1-es úton Bicske térségében található a vonzáskörzet határa. A 2-es úton - a városi csúcsokat kivéve - folyamatos a forgalmi lejtő az országhatárig, éles töréspontot a 22-es út elágazásával Rétság jelent, ahonnan Parassapusztáig jelentősen alacsonyabb a forgalom. A keresztmetszeti adatok alapján azonban nem állapítható meg, hogy a Rétság utáni forgalom hányad részben tart Vácra és hányad részben a fövárosba.

A 3-as úton a Gyöngyös utáni településektől növekszik Budapest irányába a forgalom. Azonban kizárható, hogy a napi ingázás ilyen távolságban ne a párhuzamos autópályán bonyolódna le, így a vonzáskörzet-határ megállapításához a fővároshoz közelebbi, nagy forgalombővüléssel járó pontokat kell keresni. Ennek alapján 2003-ban Gödöllö, 2007-ben Aszód térségében volt meghúzható a vonzáskörzet-határ.

A 4-es úton a Ceglédbercel környéki határvonal az ezredfordulót követően közelebb jött Pilisig, ugyanakkor az 5-ös úton nem állapíthatók meg vonzáskörzetek, a forgalmi grafikon Budapest felé lejt (13. ábra). 


\section{3. ÁBRA}

Az 5. sz. föút személygépkocsi forgalma, 2007

(Traffic Load of Cars on the Road Nr. 5, 2007)

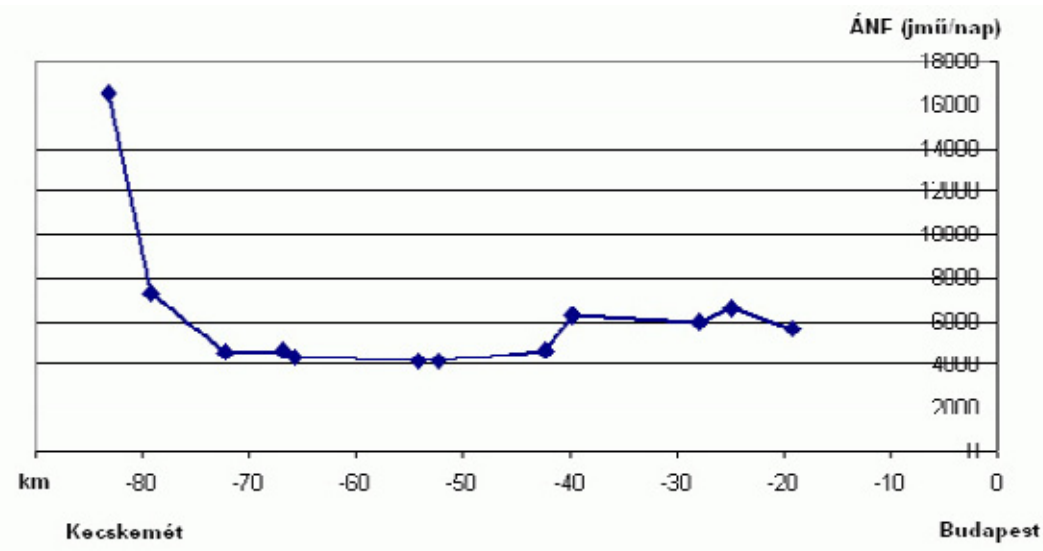

Forrás: Az országos... (2008) adatai alapján saját szerkesztés.

A 6-os úton Ercsi térségében található a vonzáskörzet határa, míg a 7-es úton Baracska és Kápolnásnyék között ingadozik a határ, átfedve ezzel Székesfehérvár vonzáskörzetét is. A 10-es úton Dorog után, Tát térségében húzódik a választóvonal, a Dunakanyar irányában pedig Tahitótfalu-Visegrád a határsáv, a forgalmi adatok jól érzékeltetik a szuburbanizáció terjedését (14. ábra).

\section{4. ÁBRA}

A 11. sz. fóút személygépkocsi forgalmának változása (Change of Traffic Load of Cars on the Road Nr. 11)

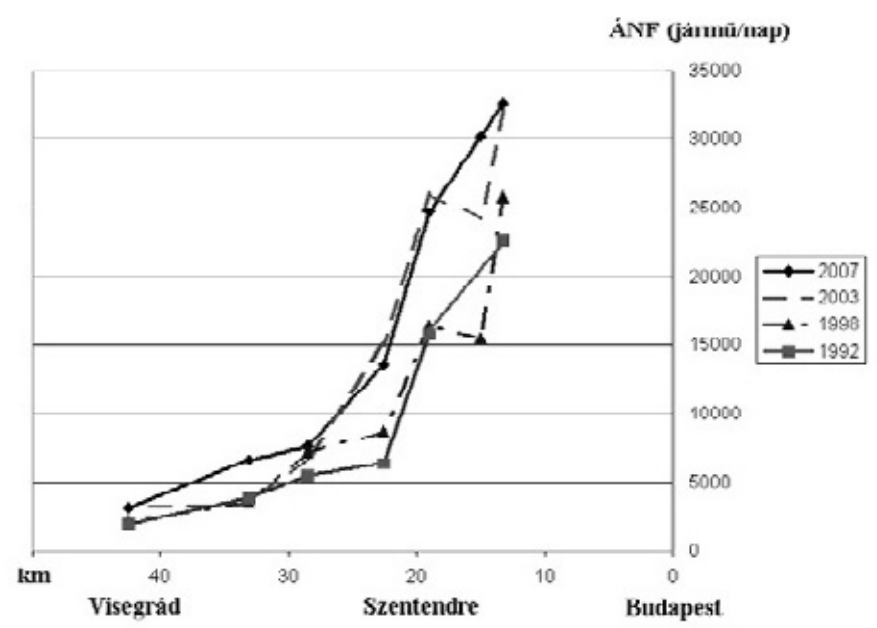

Forrás: Az országos... (1994; 1999; 2004; 2008) adatai alapján saját szerkesztés. 
A 31-es úton Nagykáta jelenti a vonzáskörzet határát. Az 51-es úton az ezredforduló előtt Solttól nőtt a forgalom Budapest felé, 2003-ban azonban Tass-Dömsöd térségéig közelebb jött a határvonal, majd 2007-ben kissé hátrébb tolódott Szalkszentmártonig.

\section{Határon átnyúló vonzáskörzetek}

A kutatásnak célja volt a határon túli nagyvárosok kapcsolatrendszerének feltárása is. E kérdés az EU-s csatlakozással tett szert nagy jelentőségre, hiszen az egykori vonzáskörzetek visszaállására nyílt ezzel történelmi esély. Négy város (Pozsony, Arad, Nagyvárad, Szatmárnémeti) változó kapcsolatrendszerének feltárására tettünk kísérletet.

Módszertani szempontból a határhatás akkor „ideális”, ha a határátkelő utáni szelvények forgalma csökkenő, de nincsen olyan mellékút, ahol a forgalom elvezetődhetne, csak település, amely elnyeli. Ideális állapotok egy vizsgált átkelő esetében sem álltak fenn, Pozsonynál nem mutatható ki a határon átnyúló hatás, mivel az M15. sz. autóut felhajtó ágain csak fiktív forgalomszámláló hely van, a régi határon átáramló forgalom nagysága pedig nem ad információt Pozsony határt átlépő vonzáskörzetéről.

A román határ menti városok közül Aradról megállapítható, hogy vonzáskörzeti forgalma Battonyánál lépi át a magyar határt. A vizsgált évek közül az utolsó háromban müködött itt átkelő, melynek adatai szerint a személygépkocsik forgalma 1434 jármüről 483 jármü/napra csökkent. Ezen adatok a várt eredményekkel ellentétes trendet tükröznek, azaz Románia EU-s csatlakozása ellenére is az utóbbi 11 évben egyre csökkenő forgalom jellemezte az átkelőt.

Ugyanígy csökkent a határon átlépő személygépkocsik száma Ártándnál (Nagyvárad) is, az 1992-es 2234 jármü helyett jelenleg csak 2150 lépi át naponta a határt. Természetesen lehetséges lenne, hogy a távolsági forgalom csökkenése mellett a helyi forgalom növekedett, erre azonban csak a környező települések (pl. Ártánd, Biharkeresztes) bejáró útjainak forgalomváltozása adhatna részleges magyarázatot. Az érintett utak forgalma azonban egymással ellentétesen változott.

A fő problémát azonban az jelenti, hogy a határállomások forgalmát az átkelőkön dolgozó személyzet regisztrálja, míg a többi pont adata a keresztmetszeti számlálásból származik. A Biharkeresztes környéki térképvázlat (15. ábra) jól szemlélteti, hogy az adatok egymással feltehetőleg nem kompatibilisek, illetve a mérőpontok sürüsége nem elégséges a keresett információk kinyeréséhez. 


\section{5. ÁBRA}

Biharkeresztes környékének személygépkocsi forgalma, 2007

(Traffic Load of Cars in the Vicinity of Biharkeresztes, 2007)

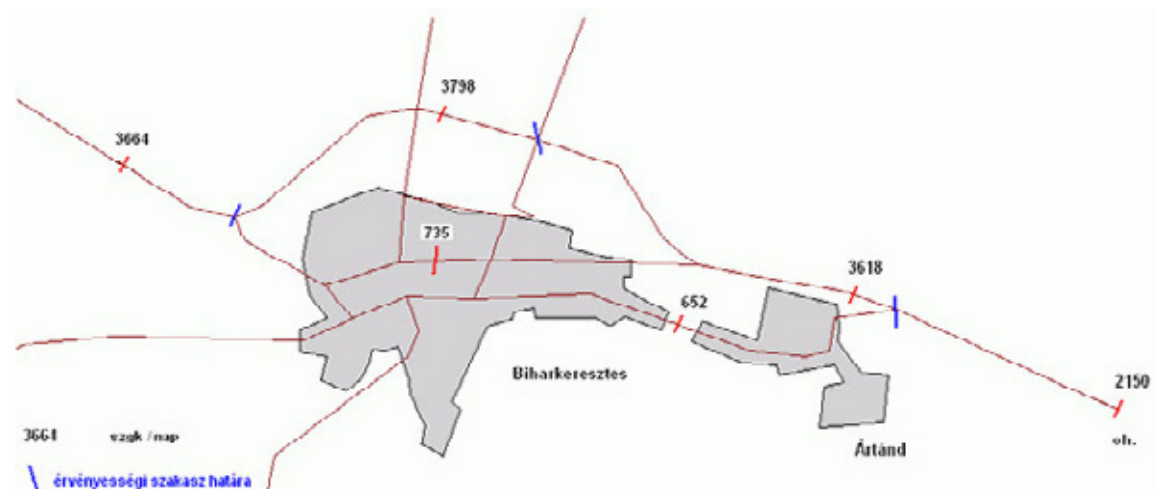

Forrás: Az országos... (2008) adatai alapján saját szerkesztés.

Végül a Szatmárnémetivel szemben fekvő Csengersima is a csökkenő forgalmú átkelőkre példa, 1992-höz képest a személygépkocsi forgalom mintegy napi 800 jármüvel, közel 40\%-kal esett vissza.

Megvizsgáltunk egy fordított esetet is, amikor a nagyváros maradt Magyarországon és vonzáskörzete került külföldre. Debrecen hatását - az eddig vizsgált átkelőkkel ellentétben - a forgalmi adatok alátámasztani látszanak. Nyírábrány forgalma arányaiban jelentősen bővült, feltételezhető, hogy ebben a határ menti kapcsolatok élénkülése, valamint Debrecen vonzáskörzetének kiterjedése játszik szerepet.

\section{Összefoglaló következtetések}

A nagyvárosok vonzáskörzetét vizsgálva megállapítható volt, hogy a forgalom a településektől távolodva több lépcsőben csökken. Közvetlenül a város mellett, 5-15 km távolságban található forgalmi szempontból a legjelentősebb töréspont, amelyet átlagosan 34 km távolságban követ az (elsődleges) vonzáskörzet-határ. Egyes települések esetében kimutatható egy távolabbi, átlagosan 58 km-re fekvő másodlagos vonzáskörzet-határ is, amely térség már csak lazábban kapcsolódik a központi településhez. Az utankénti eredményeket az 1. táblázat és a 16. ábra foglalja össze. 
1. TÁBLÁZAT

Nagyvárosaink vonzáskörzetének határa (The Border of Catchment Areas of the Hungarian Cities)

\begin{tabular}{|c|c|c|c|c|c|c|c|}
\hline Város & Útszám & $\begin{array}{c}\text { Határ } \\
{[\mathrm{km}]}\end{array}$ & $\begin{array}{l}\text { Másod- } \\
\text { lagos }\end{array}$ & $\begin{array}{l}\text { Megye- } \\
\text { határ }\end{array}$ & $\begin{array}{l}\text { Kisvá- } \\
\text { ros }\end{array}$ & $O h$ & Határtelepülés \\
\hline Pécs & 6 & 19 & & & & & Zengővárkony \\
\hline Pécs & 6 & 37 & & & $\mathrm{x}$ & & Szigetvár \\
\hline Pécs & 57 & 18 & 38 & & & & Szederkény \\
\hline Pécs & 58 & 34 & & & & $\mathrm{x}$ & oh. \\
\hline Pécs & 66 & 34 & & $x$ & $\mathrm{x}$ & & Sásd \\
\hline Győr & 1 & 23 & & $\mathrm{x}$ & & & Nagyszentjános \\
\hline Győr & 1 & 50 & & & & $\mathrm{x}$ & oh. \\
\hline Győr & 81 & 36 & & & $\mathrm{x}$ & & Kisbér \\
\hline Győr & 82 & 33 & & $\mathrm{x}$ & & & Veszprémvarsány \\
\hline Győr & 83 & 45 & & & $\mathrm{x}$ & & Pápa \\
\hline Győr & 85 & 36 & & & & & Rábatamási \\
\hline $\begin{array}{l}\text { Szombat- } \\
\text { hely }\end{array}$ & 86 & 42 & & $\mathrm{x}$ & & & Rimány \\
\hline $\begin{array}{l}\text { Szombat- } \\
\text { hely }\end{array}$ & 86 & 24 & & & & & Hegyfalu \\
\hline $\begin{array}{l}\text { Szombat- } \\
\text { hely }\end{array}$ & 87 & 23 & & & & & Kám \\
\hline $\begin{array}{l}\text { Szombat- } \\
\text { hely }\end{array}$ & 87 & 27 & & & & $\mathrm{x}$ & oh. \\
\hline $\begin{array}{l}\text { Szombat- } \\
\text { hely }\end{array}$ & 89 & 18 & & & & $\mathrm{x}$ & oh. \\
\hline Szeged & 5 & 35 & & $\mathrm{x}$ & $\mathrm{x}$ & & Kistelek \\
\hline Szeged & 5 & 16 & & & & $\mathrm{x}$ & oh. \\
\hline Szeged & 43 & 30 & & & $\mathrm{x}$ & & Makó \\
\hline Szeged & 47 & 24 & & & $\mathrm{x}$ & & Hódmezővásárhely \\
\hline Szeged & 55 & 41 & 67 & $\mathrm{x}$ & & & Öttömös \\
\hline Debrecen & 4 & 38 & & & $\mathrm{x}$ & & Püspökladány \\
\hline Debrecen & 4 & 30 & & & $\mathrm{x}$ & & Újfehértó \\
\hline Debrecen & 33 & 20 & & & & & Nagyhegyes \\
\hline Debrecen & 35 & 16 & & & $x$ & & Hajdúböszörmény \\
\hline Debrecen & 47 & 38 & & & $\mathrm{x}$ & & Berettyóújfalu \\
\hline Debrecen & 48 & 30 & & & & $\mathrm{x}$ & oh. \\
\hline Debrecen & 471 & 32 & & $\mathrm{x}$ & $\mathrm{x}$ & & Nyíradony \\
\hline Nyíregyháza & 4 & 20 & & & $\mathrm{x}$ & & Újfehértó \\
\hline Nyíregyháza & 4 & 34 & 66 & & & $\mathrm{x}$ & Demecser \\
\hline Nyíregyháza & 41 & 43 & 70 & & $\mathrm{x}$ & $\mathrm{x}$ & Baktalórántháza \\
\hline Nyíregyháza & 36 & 30 & & & $\mathrm{x}$ & & Tiszavasvári \\
\hline Nyíregyháza & 38 & 15 & & & & & $\begin{array}{l}\text { bokortanyák } \\
\text { (Virányos) }\end{array}$ \\
\hline Miskolc & 3 & 47 & & $\mathrm{x}$ & $\mathrm{x}$ & & Mezőkövesd \\
\hline Miskolc & 3 & 61 & & & & $\mathrm{x}$ & oh. \\
\hline
\end{tabular}




\begin{tabular}{|c|c|c|c|c|c|c|c|}
\hline Város & Útszám & $\begin{array}{c}\text { Határ } \\
{[\mathrm{km}]}\end{array}$ & $\begin{array}{c}\text { Másod- } \\
\text { lagos }\end{array}$ & $\begin{array}{l}\text { Megye- } \\
\text { határ }\end{array}$ & $\begin{array}{c}\text { Kisvá- } \\
\text { ros }\end{array}$ & $O h$ & Határtelepülés \\
\hline Miskolc & 26 & 44 & & & & $\mathrm{x}$ & oh. \\
\hline Miskolc & 35 & 24 & & $\mathrm{x}$ & $\mathrm{x}$ & & Tiszaújváros \\
\hline Miskolc & 37 & 26 & 65 & & $\mathrm{x}$ & & Szerencs \\
\hline Budapest & 1 & 40 & & & $\mathrm{x}$ & & Bicske \\
\hline Budapest & 2 & 55 & & & $\mathrm{x}$ & & Rétság \\
\hline Budapest & 3 & 40 & & & $\mathrm{x}$ & & Aszód \\
\hline Budapest & 4 & 45 & & & & & Pilis \\
\hline Budapest & 5 & & & & & & \\
\hline Budapest & 6 & 35 & & & & & Ercsi \\
\hline Budapest & 7 & 40 & & & & & Kápolnásnyék \\
\hline Budapest & 10 & 45 & & & $\mathrm{x}$ & & Dorog \\
\hline Budapest & 11 & 42 & & & & & Visegrád \\
\hline Budapest & 31 & 60 & & & $\mathrm{x}$ & & Nagykáta \\
\hline Budapest & 51 & 65 & & & & & Szalkszentmárton \\
\hline
\end{tabular}

Forrás: Az országos... (1994; 1999; 2004; 2008) adatai alapján saját szerkesztés.

\section{6. ÁBRA}

Nagyvárosaink vonzáskörzete a személygépkocsi forgalom nagysága alapján (Catchment Areas of the Hungarian Cities by the Traffic Load of Cars)

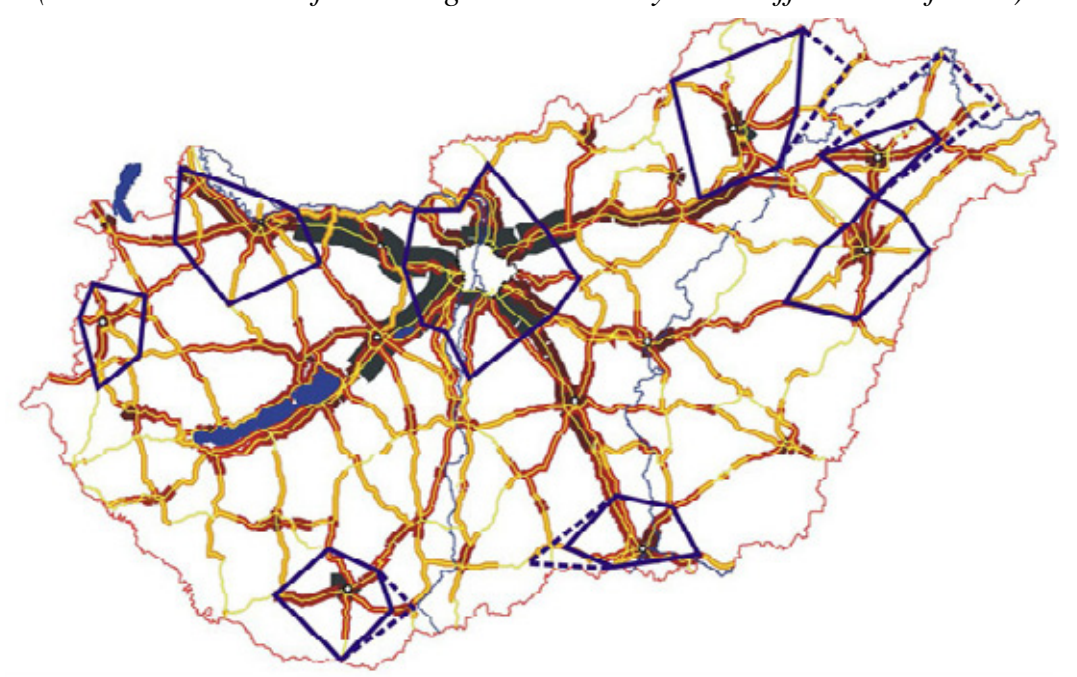

Forrás: Az országos... (1994; 1999; 2004; 2008) adatai alapján saját szerkesztés.

Az összesen 66 határpont közül 16 esik egybe megyehatárral, 35 pedig valamely közeli kisvároshoz kapcsolódik. Az országhatárok által befolyásolt vonzáskörzetek száma 11, melyek közül egyesek félbe vágják a természetes vonzáskörzetet, míg mások (pl. a Hernád völgyében) természetellenesen hosszú távolságra nyújtják meg a vonzáskörzetet az eredeti központ határon túlra került helyzete miatt. A forgalmi 
adatok alapján ugyanakkor nem mutatható ki a határon túli nagyvárosok Magyarországra való hatása, a határforgalmi adatok a vizsgált átkelők többségén csökkenő tendenciát jeleznek.

A települési értékeket összegezve megállapítható, hogy az átlagok szórása meglehetősen alacsony, a vonzáskörzet határa a települések többségénél 28 és $33 \mathrm{~km}$ közé esik, ennél magasabb értéket csak Győr és Miskolc (37-40 km), valamint a legnagyobb vonzáskörzetü főváros esetében $(47 \mathrm{~km})$ tapasztalunk (2. táblázat).

\section{TÁBLÁZAT}

Nagyvárosaink átlagos vonzáskörzeti távolsága (Average Size of Catchment Areas of the Hungarian Cities)

\begin{tabular}{lc}
\hline \multicolumn{1}{c}{ Település } & $\begin{array}{c}\text { Vonzáskörzet } \\
\text { határa }[\mathrm{km}]\end{array}$ \\
\hline Budapest & 47 \\
Debrecen & 29 \\
Györ & 37 \\
Miskolc & 40 \\
Nyíregyháza & 28 \\
Pécs & 28 \\
Szeged & 29 \\
Szombathely & 27 \\
\hline
\end{tabular}

Forrás: Az országos... (1994; 1999; 2004; 2008) adatai alapján saját szerkesztés.

A fővárostól eltekintve a vonzáskörzet nagysága nem áll összefüggésben a település lakosságszámával, és regionális jellemzők is csak annyiban tapasztalhatók, hogy egyes alföldi városok határát a nagy kiterjedésü „lakatlan” területek befolyásolják.

\section{Jegyzetek}

Adatforrások:

Az országos közutak 1992. évi keresztmetszeti forgalma. (1994) UKIG, Budapest.

Az országos közutak 1998. évre vonatkozó keresztmetszeti forgalma. (1999) ÁKMI - KTI, Budapest.

Az országos közutak 2003. évre vonatkozó keresztmetszeti forgalma. (2004) ÁKMI, Budapest.

Az országos közutak 2007. évre vonatkozó keresztmetszeti forgalma. (2008) Magyar Közút, Budapest.

\section{Irodalom}

Fodor Gy. (2006) A II. Rákóczi Ferenc Kárpátaljai Magyar Főiskola vonzáskörzetének változása 2003 és 2005 között. - Acta Beregsasiensis. 5/1. 100-111. o.

Frisnyák Zs. (2007) A magyarországi cukorgyárak vonzáskörzetei a 19. század végén. - Frisnyák S.Gál A. (szerk.) Szerencs, Dél-Zemplén központja. Nyíregyházi Főiskola, Nyíregyháza. 511-520. o.

Györi R. (2003) A Kisalföld valódi és elméleti vonzáskörzetei a XX. század elején. - Frisnyák S.- Tóth J. (szerk.) A Dunántúl és a Kisalföld történeti földrajza. Nyíregyházi Főiskola-PTE, Nyíregyháza-Pécs. 315-324. o.

Havellant O. (2005) Dunaújváros vonzáskörzetének és városi szerepének feltételezett változásai a Dunahíd megépülése után. - Csapó T. (szerk.) A településföldrajz helyzete és föbb kutatási irányai az ezredforduló után. BDF, Szombathely. 101-108. o. 
Kiss A. (1986) Dunaújváros, mint ipari centrum vonzási hatásai. - Alföldi Tanulmányok. 10. 307-325. o. Kókai S. (1998) Adalékok a dél-alföldi települések vonzáskörzeteinek vizsgálatához a XIX. század közepén. - Mészáros R.-Tóth J. (szerk.) Földrajzi kaleidoszkóp. JATE - JPTE, Szeged-Pécs. 225-244. o. Májas A. (2005) A Debreceni Egyetem külföldiekre gyakorolt vonzása. - Süli-Zakar I. (szerk.) Tájak régiók - települések. Didakt, Debrecen. 88-93. o.

Teperics K. (2005) Debrecen oktatási vonzáskörzete. - Czimre K. (szerk.) Kisközségtöl az eurórégióig. Didakt, Debrecen. 58-70. o.

Tóth J. (1974) A dél-alföldi vonzásközpontok vonzásterületeinek elhatárolása az interurbán telefonhívások alapján. - Földrajzi Értesítö. 1. 55-61. o. 